\title{
Komparasi Model Problem Based Learning Dan Discovery Learning Terhadap Hasil Belajar Ditinjau Dari Kemampuan Awal
}

\author{
${ }^{1}$ Silvia Shinta, ${ }^{2}$ Sri Fatmawati, ${ }^{3}$ Muhammad Nasir \\ 1,2,3 Jurusan Tadris Fisika, FTIK, IAIN Palangkaraya, Kalimantan Tengah \\ Email: silviashinta27@gmail.com
}

\begin{tabular}{|c|c|}
\hline Article Info & Abstract \\
\hline $\begin{array}{l}\text { Article History } \\
\text { Received: } 1 \text { December } 2020 \\
\text { Revised: } 29 \text { April } 2020 \\
\text { Published: } 30 \text { June } 2020\end{array}$ & \multirow[b]{2}{*}{$\begin{array}{l}\text { This study aims to determine: (1) Is there a difference in influence between the } \\
\text { Problem based learning and Discovery learning models on student learning } \\
\text { outcomes (2) Are there differences in influence between students with high } \\
\text { initial ability and low initial ability towards learning outcomes (3) Are there } \\
\text { interactions between the Problem based learning and Discovery learning } \\
\text { learning models with initial abilities towards learning outcomes? This study } \\
\text { aims to examine the comparative learning model of problem based learning } \\
\text { and discovery learning towards learning outcomes in terms of ability early. } \\
\text { This study used an experimental method with the only group posttest design } \\
\text { and factorial design with population of the whole MIPA class XI and sampling } \\
\text { using purposive sampling, the selected sample was XI-MIPA } 1 \text { and XI MIPA } 4 \text {. } \\
\text { The instrument used was an initial ability test and a learning achievement test. } \\
\text { The results of this study indicate that: (1) There is a significant difference in } \\
\text { influence between problem based learning and discovery learning models on } \\
\text { learning outcomes with a value of sig * } 0,000 \text { which means }<\alpha \text { where } \alpha=0.05 \\
\text { (2) There is a significant difference in influence between high initial ability and } \\
\text { low initial ability of learning outcomes with a value of sig * } 0.023 \text { which means } \\
<\alpha \text { where } \alpha=0.05 \text { (3) There is no interaction between the learning model of } \\
\text { problem based learning and discovery learning with the initial ability to } \\
\text { student learning outcomes with a value of sig * } 0.368 \text { which means }>\alpha \text { where } \alpha \\
=0.05 \text {. }\end{array}$} \\
\hline $\begin{array}{l}\text { Keywords } \\
\text { Problem based learning, } \\
\text { discovery learning mode } \\
\text { initial ability; learning } \\
\text { outcomes }\end{array}$ & \\
\hline Informasi Artikel & Abstrak \\
\hline $\begin{array}{l}\text { Sejarah Artikel } \\
\text { Diterima: } 1 \text { Desember } 2020 \\
\text { Direvisi: } 29 \text { April } 2020 \\
\text { Dipublikasi: } 30 \text { Juni } 2020\end{array}$ & \multirow[b]{2}{*}{$\begin{array}{l}\text { Penelitian ini bertujuan untuk mengetahui: (1) Apakah ada perbedaan pengaruh } \\
\text { antara model pembelajaran Problem based learning dan Discovery learning } \\
\text { terhadap hasil belajar siswa (2) Apakah ada perbedaan pengaruh antar siswa } \\
\text { yang berkemampuan awal tinggi dan kemampuan awal rendah terhadap hasil } \\
\text { belajar (3) Apakah ada interaksi model pembelajaran Problem based learning } \\
\text { dan Discovery learning dengan kemampuan awal terhadap hasil belajar. } \\
\text { Penelitian ini bertujuan untuk mengkaji komparasi model pembelajaran } \\
\text { problem based learning dan discovery learning terhadap hasil belajar ditinjau } \\
\text { dari kemampuan awal. Penelitian ini menggunakan metode eksperimen dengan } \\
\text { model only group posttest design dan factorial design dengan populasi seluruh } \\
\text { kelas XI MIPA dan pengambilan sampel menggunakan purposive sampling, } \\
\text { sampel yang dipilih yaitu kelas XI-MIPA } 1 \text { dan XI MIPA } 4 \text {. Instrumen yang } \\
\text { digunakan adalah tes kemampuan awal dan tes hasil belajar. Hasil penelitian ini } \\
\text { menunjukan bahwa: (1) Terdapat perbedaan pengaruh yang signifikan antara } \\
\text { model pembelajaran problem based learning dan discovery learning terhadap } \\
\text { hasil belajar dengan nilai sig* } 0,000 \text { yang berarti }<\alpha \text { dimana } \alpha=0,05 \text { (2) } \\
\text { Terdapat perbedaan pengaruh yang signifikan antara kemampuan awal tinggi } \\
\text { dan kemampuan awal rendah terhadap hasil belajar dengan nilai sig* } 0,023 \\
\text { yang berarti }<\alpha \text { dimana } \alpha=0,05 \text { (3) Tidak terdapat interaksi model } \\
\text { pembelajaran problem based learning dan discovery learning dengan } \\
\text { kemampuan awal terhadap hasil belajar siswa dengan nilai sig* } 0,368 \text { yang } \\
\text { berarti }>\alpha \text { dimana } \alpha=0,05 \text {. }\end{array}$} \\
\hline & \\
\hline
\end{tabular}


Sitasi: Shinta, S., Fatmawati, S., Nasir, M. (2020). Komparasi Model Problem Based Learning Dan Discovery Learning Terhadap Hasil Belajar Ditinjau Dari Kemampuan Awal. Kappa Journal. 4(1), 16-22

\section{PENDAHULUAN}

Proses pembelajaran merupakan pokok utama dari sebuah pendidikan, yang mana terjadi transfer ilmu dari pendidik kepada siswa. Ilmu tersebut akan ditransferkan pendidik melalui cara mengajar. Siswa akan cepat lupa jika guru hanya menjelaskan secara lisan tetapi siswa akan lebih lama ingat ketika diberikan contoh dari materi yang dijelaskan. Siswa akan paham materi pelajaran jika diberi suatu masalah dan mencoba memecahkan masalah (Sulistyowati, Widodo dan Sumarni, 2012). Namun, tidak semua siswa mampu memecahkan masalah yang berakibat rendahnya hasil belajar siswa. Hasil penelitian Soong, Mercer dan Shin (2009) menyatakan ada beberapa hal yang menyebabkan siswa sulit memecahkan masalah fisika, yaitu siswa tidak memahami pertanyaan, kurangnya kemampuan mengidentifikasi masalah dan kurang pemahaman konsep. Hal inilah yang menyebabkan siswa kurang paham dengan konsep atau teori yang sedang dipelajari yang berakibat rendahnya hasil belajar siswa.

Berdasarkan pengamatan selama observasi, ditemukan bahwa proses pembelajaran yang terjadi di dalam kelas kurang aktif. Siswa lebih banyak diam dan mendengarkan, sehingga membuat siswa bosan dalam proses pembelajaran terlebih siswa tidak menyukai pelajaran fisika. Berdasarkan wawancara dengan salah satu guru fisika dan observasi yang dilakukan ditemukan bahwa siswa mengalami kesulitan dalam memahami konsep fisika yang berdampak pada rendahnya hasil belajar. Melihat dari hasil penyelesaian soal-soal latihan serta tes yang dilakukan terdapat hanya $30 \%$ siswa yang mendapat nilai diatas standar kriteria ketuntasan minimal (KKM) fisika yang telah ditetapkan yaitu 70. KKM fisika yang belum tercapai menjadi salah satu faktor rendahnya hasil belajar siswa di kelas. Hasil belajar merupakan salah satu ukuran keberhasilan siswa di sekolah. Hasil belajar menurut Gagne dan Brigss (Suprihatiningrum, 2014) adalah kemampuan-kemampuan yang dimiliki siswa sebagai akibat perbuatan belajar dan dapat diamati melalui penampilan siswa. Kesulitan siswa dalam proses pembelajaran mempengaruhi hasil belajarnya. Siswa yang kesulitan dalam memahami konsep yang diajarkan berakibat rendahnya hasil belajar.

Solusi dari permasalahan di atas adalah perlu dilakukan upaya perbaikan model pembelajaran yang sesuai dengan pelajaran fisika agar mampu meningkatkan hasil belajar siswa. Model pembelajaran adalah suatu perencanaan atau pola urutan yang digunakan sebagai pedoman dalam melaksanakan pembelajaran di kelas atau pembelajaran dalam tutorial dan untuk menentukan perangkat-perangkat pembelajaran sehingga jelas kegiatan apa yang harus dilakukan guru dan siswa. Istilah model pembelajaran meliputi pendekatan yang luas dan menyeluruh (Trianto, 2014). Model pembelajaran yang sesuai dengan permasalahan diatas adalah model pembelajaran dengan pendekatan saintifik. Pendekatan saintifik adalah proses pembelajaran yang dirancang sedemikian rupa agar siswa mampu mengidentifikasi masalah, aktif mengkonstruksi konsep, merumuskan masalah, mengajukan hipotesis, mengumpulkan data dengan berbagai teknik, memadukan pengetahuan baru dengan pengetahuan sebelumnya dan menarik kesimpulan.

Model pembelajaran yang sesuai dengan permasalahan diatas adalah model pembelajaran dengan pendekatan saintifik. Dua diantara model pembelajaran yang memiliki pendekatan saintifik adalah model pembelajaran problem based learning dan model pembelajaran discovery learning. Model pembelajaran problem based learning dan discovery learning membawa siswa berpikir untuk memahami suatu permasalahan dan mencari pemecahannya berdasarkan pemahaman terkait dengan konsep yang dipelajari, sehingga siswa paham konsep atau teori yang sedang dipelajari berdasarkan permasalahan tersebut yang tentunya dapat berpengaruh terhadap keberhasilan belajar siswa. Pembelajaran berbasis 
masalah membutuhkan kemampuan untuk bertanya, mengidentifikasi, menganalisis, mengobservasi, dan mengembangkan konsep sehingga dari kemampuan-kemampuan tersebut dapat memecahkan permasalahan yang dikaji. Model pembelajaran discovery learning umumnya membutuhkan kemampuan untuk bertanya, mengobservasi, mengumpulkan informasi, mengolah informasi, dan membuat kesimpulan berdasarkan data sehingga dapat menemukan hubungan antarvariabel atau menguji hipotesis yang diajukan (Sani, 2014). Materi fisika dinamika rotasi dan kesetimbangan benda tegar cocok diterapkan dengan pembelajaran problem based learning dan discovery learning. Dalam materi ini siswa sangat terlibat karena dituntut untuk mengamati, menyelidiki dan menganalisis peristiwa yang berkaitan dengan kehidupan sehari-hari.

Namun demikian, upaya meningkatkan hasil belajar siswa terkendala pada kemampuan awal yang dimiliki siswa dalam menguasai konsep pembelajaran itu sendiri. Kemampuan awal yang dimiliki siswa juga berpengaruh dalam keberhasilan belajar siswa. Dimana kemampuan awal adalah kemampuan yang dimiliki siswa sebelum mengikuti pelajaran. Siswa sering mengalami kesulitan dalam memahami suatu pengetahuan tertentu yang salah satu penyebabnya karena pengetahuan baru yang diterima tidak terjadi hubungan dengan pengetahuan sebelumnya atau mungkin tidak memiliki pengetahuan awal (Trianto, 2014). Kemampuan awal setiap siswa berbeda-beda, karena perbedaan itulah ketika diberikan pengajaran yang sama maka akan memperoleh hasil yang berbeda. Kemampuan awal selalu berhubungan dengan proses pembelajaran. Dari kemampuan awal ketika diberikan perlakuan model pembelajaran problem based learning dan discovery learning dapat melihat perubahan hasil belajar setelah diberikan perlakuan tersebut.

Berdasarkan uraian di atas maka peneliti tertarik mengadakan penelitian yang mengkomparasikan dua model pembelajaran yang sesuai dengan mata pelajaran fisika. Model pembelajaran yang diterapkan adalah problem based learning dan discovery learning dengan melihat kemampuan awal siswa dan melihat hasil belajar setelah diterapkan kedua model tersebut. Diangkat dari permasalah tersebut, maka penelitian ini berjudul "Komparasi Model Pembelajaran Problem based learning Dan Discovery learning Terhadap Hasil Belajar Siswa Pada Pokok Bahasan Dinamika Rotasi dan Kesetimbangan Benda Tegar Kelas XI SMAN 2 Palangka Raya Ditinjau Dari Kemampuan Awal”.

\section{METODE}

Penelitian ini adalah eksperimen sederhana postest only control design dan factorial design (faktorial $2 \times 2$ ). Populasi dalam penelitian ini yaitu siswa kelas XI MIPA SMAN 2 Palangkaraya. Peneliti mengambilan sampel dengan teknik purposive sampling. Purposive sampling adalah pengambilan sampel secara sengaja dengan mempertimbangkan syarat sampel yang diperlukan. Instrumen yang digunakan dalam penelitian ini berupa tes dalam bentuk uraian. Pengambilan data diperoleh dari hasil tes yang diberikan. Sebelum diberikan tes, soal tes terlebih dahulu diukur derajat validitasnya, reliabilitas, daya beda dan taraf kesukaran. Analisis data yang digunakan adalah anava dua jalur (two way anova). Adapun design penelitian ini dapat dilihat pada tabel berikut.

Tabel 1. Design Penelitian Faktorial 2x2

\begin{tabular}{ccc}
\hline $\begin{array}{c}\text { Kemampuan } \\
\text { Awal }\end{array}$ & \multicolumn{2}{c}{ Model Pembelajaran } \\
\cline { 2 - 3 } & $\begin{array}{c}\text { Problem based } \\
\text { learning (1) }\end{array}$ & $\begin{array}{c}\text { Discovery } \\
\text { Learning (2) }\end{array}$ \\
\hline Tinggi (1) & $\boldsymbol{\mu}_{11}$ & $\boldsymbol{\mu}_{12}$ \\
\hline Rendah (2) & $\boldsymbol{\mu}_{21}$ & $\boldsymbol{\mu}_{22}$ \\
\hline
\end{tabular}

Keterangan : 


$$
\begin{aligned}
& \boldsymbol{\mu}_{11}=\text { Rata }- \text { rata kemampuan awal tinggi dengan Problem Based Learning } \\
& \boldsymbol{\mu}_{12}=\text { Rata }- \text { rata kemampuan awal tinggi dengan Discovery Learning } \\
& \boldsymbol{\mu}_{21}=\text { Rata }- \text { rata kemampuan awal rendah dengan Problem Based Learning } \\
& \boldsymbol{\mu}_{22}=\text { Rata }- \text { rata kemampuan awal rendah dengan Discovery Learning }
\end{aligned}
$$

\section{HASIL DAN PEMBAHASAN}

Hasil penelitian menggunakan analisis uji beda two way anova menunjukan nilai signifikan untuk model pembelajaran, kemampuan awal siswa dan interaksi dari ketiga variabel tersebut. Berikut tampilan hasil uji two way anova terhadap hasil penelitian.

Tabel 2. Analisis Hasil Penelitian

\begin{tabular}{ccl}
\hline Kategori & Signifikan & \multicolumn{1}{c}{ Status } \\
\hline Model Pembelajaran & 0,000 & $\mathrm{H}_{\mathrm{a}}$ diterima \\
\hline Kemampuan Awal & 0,023 & $\mathrm{H}_{\mathrm{a}}$ diterima \\
\hline Model Pembelajaran*Kemampuan Awal & 0,368 & $\mathrm{H}_{\mathrm{a}}$ ditolak \\
\hline
\end{tabular}

Hasil uji beda postest hasil belajar siswa antara kelas eksperimen 1 dan kelas eksperimen 2 diperoleh Asymp.Sig ( 2 - tailed) sebesar 0,000 karena Asymp.S ( 2 - tailed $)<$ 0,05 maka Ho ditolak dan Ha diterima yang artinya terdapat perbedaan yang signifikan nilai postest hasil belajar siswa antara kelas eksperimen 1 dengan kelas eksperimen 2 setelah diberi perlakuan. Selain itu, pada kelas eksperimen 1 nilai rata-rata postest sebesar 80,30 dan pada kelas eksperimen 2 nilai rata-rata postest sebesar 77,86.

Perbedaan hasil belajar siswa kelas eksperimen 1 dan eskperimen 2 terjadi karena siswa pada kelas eksperimen 1 dengan problem based learning lebih mudah memahami karena diberikan permasalahan-permasalahan dan siswa tertantang mencari pemecahan masalah tersebut. Problem based learning membutuhkan kemampuan bertanya, mengidentifikasi dan menganalisis masalah, mengobservasi, mengumpulkan, mengolah data dan mengembangkan konsep sehingga dapat menyelesaikan permasalahan. Permasalahan yang diberikan dan rangkaian kegiatan pembelajaran problem based learning dapat meningkatkan kemampuan pemecahan masalah siswa yang berdampak posistif terhadap hasil belajar. Karena memungkinkan siswa dapat memecahkan permasalahan itulah yang menyebabkan model pembelajaran problem based learning lebih optimal dalam meningkatkan hasil belajar.

Melalui pengamatan peneliti suasana belajar yang terjadi di kelas eksperimen 1 dan eksperimen 2 sangat jauh berbeda. Siswa pada kelas eksperimen 1 dengan model pembelajaran problem based learning lebih antusias dalam belajar, fokus dan aktif. Siswa dalam kelas ini sangat semangat dalam melaksanakan praktikum dan aktif dalam presentasi hasil praktikum. Sebagian besar siswa pada kelas ini berani menyanggah dan menyampaikan pendapat saat presentasi kelompok. Sedangkan siswa pada kelas eksperimen 2 yang diterapkan model pembelajaran discovery learning kurang semangat dalam belajar dan tidak fokus. Tidak berani menyampaikan pendapat apalagi menyanggah ketika kegiatan diskusi dan presentasi hasil praktikum. Siswa cenderung diam dan tidak berusaha mencari penemuan terkait praktikum yang dilakukan.

Hasil penelitian ini ialah nilai hasil belajar kelas eksperimen 1 yang menerapkan model pembelajaran problem based learning lebih tinggi daripada kelas eksperimen 2 yang menerapkan model pembelajaran discovery learning. Hal ini sejalur dengan penelitian yang 
dilakukan Rahayu, Undang dan Abdurahman (2015) dengan hasil penelitian menunjukan bahwa model pembelajaran problem based learning lebih efektif meningkatkan hasil belajar. Model pembelajaran problem based learning memberikan pengaruh terhadap hasil belajar siswa. Penelitian ini juga bertentangan dengan penelitian yang dilakukan oleh Suminar dan Meylani (2019) dengan hasil penelitian menunjukan bahwa model pembelajaran discovery learning berpengaruh terhadap hasil belajar dan sangat cocok meningkatkan hasil belajar dibandingkan dengan problem based learning. Dengan melihat dari pengamatan dan hasil penelitian dapat disimpulkan pada penelitian ini bahwa model pembelajaran problem based learning memberikan pengaruh yang tinggi terhadap hasil belajar siswa.

Hasil uji beda kedua kemampuan awal antara siswa yang berkemampuan awal tinggi dan berkemampuan awal rendah diperoleh Asymp.Sig (2 - tailed) sebesar 0,023 karena Asymp.S $(2$ - tailed $)<0,05$ maka Ho ditolak dan Ha diterima yang artinya terdapat perbedaan yang signifikan antara siswa yang berkemampuan awal tinggi dan yang berkemampuan awal rendah terhadap hasil belajar. Uji beda menunjukan nilai signifikan sebesar 0,023 yang menyatakan terdapat perbedaan pengaruh yang signifikan antara siswa yang berkemampuan awal tinggi dan yang berkemampuan awal rendah terhadap hasil belajar. Hal ini sejalur dengan penelitian yang dilakukan oleh Anggraini dan Mukhadis (2013) dengan hasil penelitian menunjukan bahwa terdapat perbedaan antara siswa yang berkemampuan awal tinggi dan berkemampuan awal rendah terhadap hasil belajar.

Melalui pengamatan peneliti siswa yang memiliki kemampuan awal tinggi lebih siap dan lecih cepat paham dengan materi yang diberikan. Selain itu, siswa kelompok ini terlihat lebih antusias dalam belajar, aktif bertanya, berani mengutarakan pendapatnya dan berani menyanggah. Sedangkan siswa yang berkemampuan awal rendah kurang siap menerima pelajaran dan sulit memahami pelajaran. Siswa kelompok ini cenderung diam dan kurang aktif dalam berdiskusi. Siswa yang berkemampuan awal rendah tidak berani bertanya, tidak berani menyampaikan pendapat dan kurang mampu berdiskusi dengan teman kelompok. Penelitian lain (Rasyid, Pasaribu, dan Kamaluddin, 2015) menyatakan siswa yang berkemampuan awal tinggi memiliki keingintahuan yang besar daripada siswa yang memiliki kemampuan awal rendah yang cenderung pasif didalam proses pembelajaran.

Siswa yang memiliki kemampuan awal tinggi lebih mudah mengingat informasi yang telah diperoleh dan lebih cepat memahami materi yang sedang dipelajari (Muammar, Harjono, dan Gunawan , 2017). Hal inilah yang menyebabkan adanya perbedaan hasil belajar antara siswa yang berkemampuan awal tinggi dan rendah. Jadi, dapat disimpulkan bahwa hasil belajar siswa dengan kemampuan awal tinggi lebih tinggi daripada siswa yang berkemampuan awal rendah. Dengan demikian, tampak bahwa kemampuan awal mempengaruhi hasil belajar siswa.

Hasil uji beda interaksi model pembelajaran problem based learning dan discovery learning dengan kemampuan awal terhadap hasil belajar pada pokok bahasan dinamika rotasi dan kesetimbangan benda tegar diperoleh Asymp.Sig (2 - tailed) sebesar 0,368 karena Asymp.S $(2$ - tailed $)>0,05$ maka Ho diterima dan Ha ditolak yang berarti tidak ada interaksi model pembelajaran problem based learning dan discovery learning dengan kemampuan awal terhadap hasil belajar pada pokok bahasan dinamika rotasi dan kesetimbangan benda tegar.

Pada penelitian ini pengaruh yang diberikan oleh model pembelajaran problem based learning dan discovery learning terhadap hasil belajar adalah pengaruh yang berdiri sendiri dan tidak ada hubungannya dengan kemampuan awal. Begitu pula sebaliknya, pengaruh yang diberikan kemampuan awal terhadap hasil belajar adalah pengaruh yang berdiri sendiri dan tidak berhubungan dengan model pembelajaran. Siswa yang memiliki kemampuan awal tinggi akan mendapatkan hasil belajar yang tinggi pula walaupun diterapkan model pembelajaran yang berbeda. Hasil penelitian ini selajur dengan penelitian yang dilakukan Nurfauzia, Kaharuddin dan Khaeruddin (2019) dengan hasil penelitian tidak terjadinya 
interaksi antara model pembelajaran ditinjau dari pengetahuan awal yang dimiliki siswa terhadap hasil belajar fisika. Penelitian lain (Muammar, Harjono, dan Gunawan, 2017) juga mengemukakan semakin tinggi kemampuan awal siswa semakin tinggi pula hasil belajar walaupun menggunakan model pembelajaran apapun. Pengaruh yang diberikan kemampuan awal terhadap hasil belajar tidak ada hubungannya dengan model pembelajaran. Model pembelajaran berdiri sendiri dan tidak berkaitan dengan kemampuan awal yang dimiliki siswa. Dengan demikian, antara model pembelajaran problem based learning dan discovery learning, kemampuan awal dan hasil belajar bisa berjalan sendiri tanpa saling terikat dan mempengaruhi ketiga variabel tersebut.

\section{KESIMPULAN}

Berdasarkan hasil dan pembahasan sebelumnya, maka dapat dilihat dan disimpulkan adanya perbedaan pengaruh yang menggunakan model pembelajaran problem based learning dan discovery learning terhadap hasil belajar dilihat dari nilai rata-rata postest dan menggunakan analisis two way anova. Nilai rata-rata postest kelas eksperimen 1 sebesar 80,30 sedangkan nilai rata-rata postest kelas eksperimen 2 sebesar 77,86. Perbedaan pengaruh yang signifikan antara model pembelajaran problem based learning dan discovery learning terhadap hasil belajar pada materi dinamika rotasi dan kesetimbangan benda tegar dengan taraf signifikan 0,000 yang berarti $<\alpha$ dimana $\alpha=0,05$. Nilai rata-rata postest kelas eksperimen 1 yang menggunakan model pembelajaran problem based learning lebih tinggi daripada kelas eksperimen 2 yang menggunakan model pembelajaran discovery learning.

Perbedaaan pengaruh kemampuan awal tinggi dan kemampuan awal rendah terhadap hasil belajar menggunakan analisis statistik uji beda two way anova. Hasil analisis menunjukan terdapatnya perbedaan pengaruh yang signifikan antara kemampuan awal tinggi dan kemampuan awal rendah terhadap hasil belajar pada materi dinamika rotasi dan kesetimbangan benda tegar dengan taraf signifikan 0,023 yang berarti $<\alpha$ dimana $\alpha=0,05$.

Untuk melihat ada tidaknya interaksi antara model pembelajaran problem based learning dan discovery learning dengan kemampuan awal terhadap hasil belajar menggunakan analisis statistik uji beda two way anova. Hasil analisis menunjukan tidak terdapat interaksi model pembelajaran problem based learning dan discovery learning dengan kemampuan awal terhadap hasil belajar siswa dengan taraf signifikan 0,368 yang berarti > $\alpha$ dimana $\alpha=0,05$.

\section{SARAN}

Penelitian ini menggunakan model pembelajaran yang tergolong baru yaitu problem based learning dan discovery learning. Saran untuk penelitian selanjutnya untuk menggunakan sekolah atau kelas yang benar-benar mampu menggunakan model pembelajaran tersebut. Diharapkan menggunakan model pembelajaran tersebut tercipta proses pembelajaran yang baik dan aktif dan dapat digunakan untuk meningkatkan kualitas pembelajaran guru di kelas.

\section{UCAPAN TERIMAKASIH}

Penelitian ini terselenggara berkat kuasa Allah SWT dan bantuan dari berbagai pihak, yaitu IAIN Palangkaraya dan SMAN 2 Palangkaraya. Bersama ini kami tim peneliti mengucapkan terimakasih atas kerjasama dan segala bantuannya.

\section{DAFTAR PUSTAKA}

Anggraini, V. D., \& Mukhadis, A. (2013). Problem Based Learning, Motivasi Belajar, Kemampuan Awal, Dan Hasil Belajar Siswa SMK. Jurnal Ilmu Pendidikan, 19(2). 
Muammar, H., Harjono, A., \& Gunawan, G. (2017). Pengaruh Model Pembelajaran Assure dan Pengetahuan Awal Terhadap Hasil Belajar IPA-Fisika Siswa Kelas VIII SMPN 22 Mataram. Jurnal Pendidikan Fisika dan Teknologi, 1(3), 166-172.

Nurfauzia, N. Kaharuddin, A. Khaeruddin. (2019). Pengaruh Model Pembelajaran Penemuan Dan Pengetahuan Awal Terhadap Hasil Belajar Fisika Siswa Kelas Xi Mia Sman 16 Makassar (Doctoral Dissertation, Pascasarjana).

Rahayu, Puspita. Indah., Rosidin, Undang., \& Abdurrahman, A. (2015). Perbandingan Hasil Belajar Siswa antara Pembelajaran Menggunakan PBL dan Discovery Learning. Jurnal Pembelajaran Fisika Universitas Lampung, 3(5).

Rasyid, A., Passaribu, M., \& Kamaludin, H. (2015). Pengaruh Model Pembelajaran Kooperatif Tipe Nht (Numbered Heads Together) dan Kemampuan Awal Terhadap Hasil Belajar Siswa Pada Mata Pelajaran Fisika Di SMP Negeri 2 Poso. Jurnal Mitra Sains, 3(1).

Sani, Abdullah, Ridwan. (2014). Pembelajaran Saintifik Untuk Implementasi Kurikulum 2013. Jakarta : Bumi Aksara.

Soong, B., Mercer, N., \& Er, S. S. (2009). Students' difficulties when solving physics problems: Results from an ICT-infused revision intervention. In Proceedings of the 17th International Conference on Computers in Education (ICCE).

Sulistyowati, N., Widodo, A. T. W. T., \& Sumarni, W. (2012). Efektivitas model pembelajaran guided discovery learning terhadap kemampuan pemecahan masalah kimia. Chemistry in education, 1(2).

Suminar, Serra. Oktafoura., \& Meilani, Rini. Intansari. (2016). Pengaruh Model Pembelajaran Discovery Learning dan Problem based learning Terhadap Prestasi Belajar Siswa. Jurnal Pendidikan Manajemen Perkantoran, 1(1).

Suprihatiningrum, Jamil. (2012). Strategi Pembelajaran. Yogyakarta : A-Ruzz Media.

Trianto. 2014. Mendesain Model Pembelajaran Inovatif, Progresif, Dan Kontekstual.Jakarta : Prenadamedia Group 